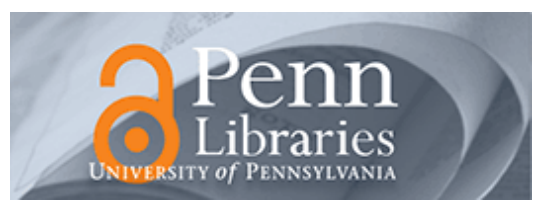

Manuscript Studies

Volume 4 | Issue 2

Article 4

2019

\title{
Visualizing Codicologically and Textually Complex Manuscripts
}

Anna Dorofeeva

University College Dublin, a.dorofeeva@gmail.com

Follow this and additional works at: https://repository.upenn.edu/mss_sims

Part of the Digital Humanities Commons, and the Medieval Studies Commons

\section{Recommended Citation}

Dorofeeva, Anna (2019) "Visualizing Codicologically and Textually Complex Manuscripts," Manuscript Studies: Vol. 4 : Iss. 2 , Article 4.

Available at: https://repository.upenn.edu/mss_sims/vol4/iss2/4

This paper is posted at ScholarlyCommons. https://repository.upenn.edu/mss_sims/vol4/iss2/4

For more information, please contact repository@pobox.upenn.edu. 


\title{
Visualizing Codicologically and Textually Complex Manuscripts
}

\begin{abstract}
This article presents the collation map, a new diagrammatic method for visually mapping the texts of complex medieval Western manuscripts against their material structures. It argues that the collation map is a more useful tool for understanding the collation of codicologically and textually complex manuscripts than collation formulae - currently the most frequently used method of representing collation. Four reasons for this are explored: one, the map provides a visual representation of the manuscript's overall structure at a glance by showing the whole manuscript on a single page; two, it provides an instant overview of the size and spread of texts between quires, recognizing the importance of manuscript contents both for collation and for the growing movement to view manuscript books as whole objects; three, it is a useful working aid when examining digital manuscripts, and an essential aid to scholarship in an increasingly digital and international environment; and four, unlike formulae, the collation map avoids prescribing a set of theoretical standards or a national system. The article couches these discussions within the context of the full range of published work in theoretical codicology.
\end{abstract}

\section{Keywords}

Manuscript studies, collation, diagram, visualization, codicology, manuscripts 


\title{
MANUSCRIPT STUDIES
}

A Journal of the Schoenberg Institute for Manuscript Studies

\author{
VOLUME 4, NUMBER 2
}

(Fall 2019)

Manuscript Studies (ISSN 2381-5329) is published semiannually

by the University of Pennsylvania Press

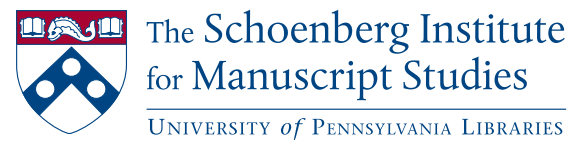




\section{MANUSCRIPT STUDIES}

VOLUME 4, N U M B E 2

(Fall 2019)

ISSN 2381-5329

Copyright (C 2019 University of Pennsylvania Libraries

and University of Pennsylvania Press. All rights reserved.

Published by the University of Pennsylvania Press, 3905 Spruce Street, Philadelphia, PA 19104.

Printed in the U.S.A. on acid-free paper.

Manuscript Studies brings together scholarship from around the world and across disciplines related to the study of premodern manuscript books and documents, with a special emphasis on the role of digital technologies in advancing manuscript research. Articles for submission should be prepared according to the Chicago Manual of Style, $16^{\text {th }}$ edition, and follow the style guidelines found at http://mss.pennpress.org.

None of the contents of this journal may be reproduced without prior written consent of the University of Pennsylvania Press. Authorization to photocopy is granted by the University of Pennsylvania Press for libraries or other users registered with Copyright Clearance Center (CCC) Transaction Reporting Service, provided that all required fees are verified with CCC and paid directly to CCC, 222 Rosewood Drive, Danvers, MA 01923. This consent does not extend to other kinds of copying for general distribution, for advertising or promotional purposes, for creating new collective works, for database retrieval, or for resale.

\section{SUBSCRIPTION INFORMATION:}

Single issues: $\$ 30$

Print and online subscriptions: Individuals: $\$ 40$; Institutions: $\$ 92$; Full-time Students: $\$ 30$ International subscribers, please add $\$ 19$ per year for shipping.

Online-only subscriptions: Individuals: $\$ 32$; Institutions: $\$ 80$

Please direct all subscription orders, inquiries, requests for single issues, address changes, and other business communications to Penn Press Journals, 3905 Spruce Street, Philadelphia, PA 19104. Phone: 215-573-1295. Fax: 215-746-3636. Email: journals@pobox.upenn.edu. Prepayment is required. Orders may be charged to MasterCard, Visa, and American Express credit cards. Checks and money orders should be made payable to "University of Pennsylvania Press" and sent to the address printed directly above.

One-year subscriptions are valid January 1 through December 31. Subscriptions received after October 31 in any year become effective the following January 1. Subscribers joining midyear receive immediately copies of all issues of Manuscript Studies already in print for that year.

Postmaster: send address changes to Penn Press Journals, 3905 Spruce Street, Philadelphia, PA 19104.

Visit Manuscript Studies on the web at mss.pennpress.org. 


\section{MANUSCRIPT STUDIES}

\section{A Journal of the Schoenberg Institute for Manuscript Studies}

V OL U M E 4, N U M B E R 2

\section{Articles}

Moralizing the Mass in the Butler Hours

KATHRYN A. SMith

Clockwise-Counterclockwise: Calligraphic Frames in Sephardic Hebrew Bibles and Their Roots in Mediterranean Culture

Dalia-Ruth Halperin

Breaking and Remaking Scripture: The Life, Death, and Afterlife of the Hornby-Cockerell Bible

ERIC J. JOHNSON

Visualizing Codicologically and Textually

Complex Manuscripts

Anna Dorofeeva

Multispectral Recovery of a Fragment of Richard FitzRalph's

Summa de Questionibus Armenorum from University of

Rochester, D.460 1000-03

Kyle Ann Huskin, Alexander J. Zawacki, Gregory Heyworth

\section{Annotations}

Two Unusual Mind Diagrams in a Late Fifteenth-Century

Manuscript (UPenn Schoenberg Collection, LJS 429)

Mary J. Carruthers

Labecule Vivex: Building a Reference Library of Stains

for Medieval and Early Modern Manuscripts

Alberto Campagnolo, Erin Connelly, Heather Wacha 
Manuscript Studies, Vol. 4 [2019], Iss. 2, Art. 4

iv | Journal for Manuscript Studies

\section{Reviews}

Mauro Nobili and Andrea Brigaglia, eds.

The Arts and Crafts of Literacy: Islamic Manuscript

Cultures in Sub-Saharan Africa.

Evyn KropF

Catherine A. Bradley and Karen Desmond, eds. The

Montpellier Codex: The Final Fascicle. Contents, Contexts,

Chronologies.

Flannery CUNNINGHAM

Laura Cleaver and Andrea Worm, eds. Writing History in the Anglo-Norman World: Manuscripts, Makers, and Readers, $c$. 1066-c. 1250.

JaCQueline M. Burek

Mariken Teeuwen and Irene van Renswoude, eds.

The Annotated Book in the Early Middle Ages:

Practices of Reading and Writing.

Christine E. BACHMAN 


\title{
Visualizing Codicologically and Textually Complex Manuscripts
}

\author{
Anna Dorofeeva \\ University College Dublin
}

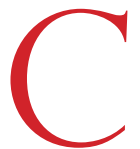

OLLATION FORMULAE ARE THE primary means by which the material structures of Western medieval codices, whose basic unit is the folded sheet arranged into quires, can be represented. Formulae are, undeniably, a useful tool both of descriptive bibliography and of codicology. A range of difficulties associated with the use of collation formulae now exist, however, in the light of recent developments in structural codicology as well as a growth in the number of studies that aim to examine manuscripts as whole objects within their cultural contexts rather than simply as carriers of texts. ${ }^{1}$ These developments demand precise descriptions of the material structures of medieval books that take into account changes over time, and they make it more often necessary to establish how

1 These include, for example, Albert Derolez, The Making and Meaning of the Liber Floridus: A Study of the Original Manuscript Ghent, University Library MS 92 (Turnhout: Brepols, 2015); and Felice Lifshitz, Religious Women in Early Carolingian Francia: A Study of Manuscript Transmission and Monastic Culture (New York: Fordham University Press, 2014). The history of structural codicology as a discipline and the particular codicological problems of complex manuscripts, which are too many to list here, are lucidly explained in Patrick Andrist, Paul Canart, and Marilena Maniaci, La syntaxe du codex: essai de codicologie structurale (Turnhout: Brepols, 2013). See also Michael Friedrich and Cosima Schwarke, eds., One-Volume Libraries: Composite and Multiple-Text Manuscripts, Digital original edition (Berlin: De Gruyter, 2016), particularly the article by Marilena Maniaci, "The Medieval Codex as a Complex Container: The Greek and Latin Traditions," 27-46. 
and when texts were copied during the production process of the physical book. This is particularly important for codicologically and textually complex manuscripts. Since collation formulae aim to describe the collation of manuscripts as they exist today-though, as we shall see below, they are associated with the idea of an "ideal copy" and retain some of its principles-they cannot meet these requirements on their own. Diagrammatic visualization of manuscript collation is one increasingly viable solution in the rapidly growing field of digital manuscript studies. ${ }^{2}$ This article proposes the collation map, a new kind of diagram for representing the material structure and contents of complex medieval books, as a digital tool that also avoids some of the problems associated with formulae. The article reviews the history of collation formulae and quire tables as methods of representing collation, before discussing the features and advantages of the collation map in comparison with formulae and in light of developments in the digital sphere. This is followed by conclusions and an appendix listing the contents of the example manuscripts Bern, Burgerbibliothek, M. lat. 611 + Paris, Bibliothèque nationale de France, MS lat. 10756.

\section{Representing Manuscript Structures: Collation Formulae and Quire Tables}

As we have already noted, the principal way to represent the distribution and composition of quires or gatherings within a Western medieval manuscript so far has been by means of a collation formula and sometimes a quire table-except in France and Italy, where descriptions are often preferred. These methods are worth reviewing briefly. ${ }^{3}$ There exist at least three kinds of manuscript collation formulae, with at least one more for printed books.

2 For summary hard copies such as catalogs, where economy of space is a priority, formulae may still be preferable.

3 Much of this information is taken from Frank Michael Bischoff, "Methoden der Lagenbeschreibung," Scriptorium 46 (1992): 3-27. It is, however, necessary to summarize it here for non-German speakers, and to remind the reader of the sometimes opaque history of collation as a bibliographical method. 


\section{Dorofeeva: Visualizing Codicologically and Textually Complex Manuscripts}

\section{6 | Journal for Manuscript Studies}

I shall focus here on formulae for manuscript rather than print books. ${ }^{4}$ As scholars of descriptive bibliography know, in the English-speaking world, in some Eastern European countries and in the Netherlands, these formulae are based on the ideas of Henry Bradshaw (which he applied equally to both manuscripts and printed books), and to a lesser extent on Fredson Bowers's Principles of Bibliographical Description. Philip Gaskell's A New Introduction to Bibliography and Walter W. Greg's "Formulary of Collation" have also been influential. Richard Beadle's published Sandars Lectures summarize many of these contributions. ${ }^{5}$ Catalogers and bibliographers used Bradshaw's collation formulae well before N. R. Ker, but it was Ker who established a clear set of guidelines for encoding collation in his catalogs, which many codicologists now follow. ${ }^{6}$ In German-speaking countries as well as in Belgium, Sweden, and sometimes the Netherlands, the formulae are based on the model proposed by Anton Chroust (preceded in the field by Karl Dziatzko, whose model is no longer used). ${ }^{7}$ Hybrid forms of all these formula models are also found.

4 For more information on modern uses of manuscript formulae and methods of collation description, see Maria Luisa Agati, Il libro manoscritto da Oriente a Occidente: per una codicologia comparata (Rome: "L’Erma" di Breitschneider, 2009); Paul Géhin, Lire le manuscrit médiéval: observer et décrire (Paris: Armand Colin, 2017); and Giuseppina Zappella, Manuale del libro antico: guida allo studio e alla catalogazione (Milan: Editrice Bibliografica, 1996).

5 Fredson Bowers, Principles of Bibliographical Description (Winchester: Oak Knoll, 1949); Paul Needham, The Bradshaw Method: Henry Bradshaw's Contribution to Bibliography (Chapel Hill, NC: Hanes Foundation, 1988); Philip Gaskell, A New Introduction to Bibliography (New Castle, DE: Oak Knoll, 2007); Walter Wilson Greg, “A Formulary of Collation,” The Library: The Transactions of the Bibliographical Society 14 (1934): 365-82; and Richard Beadle, Henry Bradshaw and the Foundations of Codicology: The Sandars Lectures 2015 (Cambridge: Privately printed, 2017).

6 Neil Ripley Ker, Catalogue of Manuscripts Containing Anglo-Saxon (Oxford: Clarendon, 1957), and his introductions in Medieval Manuscripts in British Libraries, vols. 1 and 2 (Oxford: Clarendon, 1969-76). Among other early catalogs to use Bradshaw's collation method was John Young and Patrick Henderson Aitken, A Catalogue of the Manuscripts in the Library of the Hunterian Museum in the University of Glasgow (Glasgow: James Maclehose \& Sons, 1908). 7 Anton Chroust, “Unedierte Königs- und Papst-Urkunden,” Neues Archiv 16 (1891): 135-68; idem, Monumenta Palaeographica. Denkmäler der Scbreibkunst des Mittelalters: Abt.1 Schrifttafeln in lateinischer und deutscher Sprache (Munich: Bruckmann, 1901); and idem, "Das Wahldekret Anaklets II,” Mitteilungen des Instituts für Österreichische Geschicbtsforschung 28 


\section{Manuscript Studies, Vol. 4 [2019], Iss. 2, Art. 4}

Among some of the more common formulae now in use are the following, listed in no particular order and here representing, as an example, the first seven quires of Bern, Burgerbibliothek, MS lat. 611 (further discussed below).

1. The formula used by M. R. James and N. R. Ker, among others. Following Bradshaw, they took quires composed of bifolia as the formula's basis, and recorded any deviations from these. ${ }^{8}$ In this type of formula, Arabic numerals indicate the sequence of quires in order from first to last; the superscript number, the size of quire in terms of the number of regularly paired leaves, whether conjugate (binio, quaternio, quinio, etc.) or coupled (a non-conjugate pair acting as a surrogate for a conjugate pair); and the brackets, the number and the location of missing or added leaves. ${ }^{9}$ Ker also supplemented his formulae with explanations when they were needed, including the folio numbers of quires in brackets (which are not shown here):

$$
\begin{aligned}
& 1^{6+2}(1 \text { leaf after } 2 \text { and } 1 \text { leaf after } 5)+2^{6+2}(1 \text { leaf after } 2 \text { and } 1 \text { leaf } \\
& \text { after } 5)+3^{2+1} \text { (leaf } 1 \text { is sewn separately onto leaf } 2 \text { using a stub }
\end{aligned}
$$

(1908): 348-55; Karl Dziatzko, “Über Inkunabelkatalogisierung,” in Karl Dziatzko, ed., Beiträge zur Kenntnis des Schrift-, Buch- und Bibliothekswesens (Leipzig: M. Spirgatis, 1896), 94-133. See Bischoff, "Methoden," 10, for an outline of the historiography in Germany.

8 M. R. James, The Western Manuscripts in the Library of Trinity College, Cambridge: A Descriptive Catalogue, vol. 1: Containing an Account of the Manuscripts Standing in Class B (Cambridge: Cambridge University Press, 1900); Ker, Catalogue of Manuscripts. As Dane noted, Bradshaw did not absolutely insist that each quire had to have an even number of matching leaves in bifolia, whether real or conjugate, but rather thought that an uneven number of leaves always merited investigation. Nevertheless, he has been credited with the idea that a conjugate is necessary for each leaf by Paul Needham in his study of Bradshaw's work, and many subsequent bibliographers have also adopted this principle. See Joseph A. Dane, Abstractions of Evidence in the Study of Manuscripts and Early Printed Books (Farnham: Routledge, 2009), 122 n. 4; and Needham, The Bradshaw Method, 24-33.

9 James additionally used lower-case letters in his collation of end-leaves to differentiate them from the collation of the other quires. The term "coupled leaves" was first used by J. P. Gumbert, "Skins, Sheets and Quires," in Derek Pearsall, ed., New Directions in Later Medieval Manuscript Studies. Essays from the 1998 Harvard Conference (Woodbridge: Boydell, 2000), 81-90. 
fold $)+4^{8-1}$ (missing leaf 5$)+5^{8}+6^{6+1}$ (added leaf 1 glued to leaf 7 due to broken stub fold $)+7^{8}$

2. A variant on Bradshaw's formula, which does not assume regularly paired leaves as the basic unit of the quires. In this variant, Arabic numerals indicate the quires in order from first to last; the superscript number, the quantity of single leaves in each; and the brackets, the folio number of the final leaf in the quire: ${ }^{10}$

$$
\begin{aligned}
& \left.\left.\left.\left.\left.\left.1^{8} \text { (f. } 8\right)+2^{8} \text { (f. } 16\right)+3^{3} \text { (f. } 19\right)+4^{7} \text { (f. } 26\right)+5^{8} \text { (f. } 34\right)+6^{7} \text { (f. } 41\right)+ \\
& \left.7^{8} \text { (f. } 49\right)
\end{aligned}
$$

3. The "German" formula, based on Chroust's model, where Roman numerals indicate the type of quire, a plus or minus sign indicates added or missing leaves, and the superscript number indicates the number of the final folio of the quire:

$$
(\mathrm{III}+2)^{8}+(\mathrm{III}+2)^{16}+(\mathrm{II}+1)^{19}+(\mathrm{IV}-1)^{26}+\mathrm{IV}^{34}+(\mathrm{VI}+1)^{41}+\mathrm{IV}^{49}
$$

All three models omit certain kinds of information-for instance, the first does not record the foliation of the final leaf in each quire, the second does not record the size of each quire, and both the second and third do not indicate the position within the quire of missing or added leaves. Variations, from the simple to the complex, exist for all these formulae, in order to solve these and other problems, and are too many to be listed here. ${ }^{11}$ It should

10 This variant is also called the "English" formula in Alessandro Bausi, Pier Giorgio Borbone, Françoise Briquel-Chatonnet, Paola Buzi, Jost Gippert, Caroline Macé, Marilena Maniaci, Zisis Melissakis, Laura E. Parodi, and Witold Witakowski, eds., Comparative Oriental Manuscript Studies: An Introduction (Hamburg: Tredition, 2015), 524, doi:10.5281/ zenodo.46784. This formula is sometimes used in British manuscript catalogs but is perhaps more common in Canada and the United States, for example, as well as in other countries. It should be noted that national standards for quire formulae do not exist, and when national descriptors are used, they must be more or less arbitrary.

11 A common variation on the first formula that is used, for example, in France, replaces the somewhat outdated "wants" with a minus sign in the exponent and encloses the whole in 
Manuscript Studies, Vol. 4 [2019], Iss. 2, Art. 4

also be noted that completely different conventions are customarily used for Arabic manuscripts. ${ }^{12}$

Quire tables emerged not long after collation formulae, and can also vary. They were first used by Ludwig Traube in 1902, and were further developed by Allan Stevenson, Theo Gerardy, and Jacques Lemaire in the second half of the twentieth century. ${ }^{13}$ Such tables provide a way to list quires in order in the first column, with further columns to the right supplying information such as quire signatures, disposition of flesh and hair sides, the location of the centerfold of each quire, the foliation of each quire, leaves added or removed, and so on. The information and the means of displaying it in each table varies depending on the particular focus of study. Quire tables are used principally by French and German-speaking scholars, but their complexity means that they appear only in more specialized publications. $^{14}$

Despite their ability to encode complex information about the material structures of manuscripts, both collation formulae and quire tables are increasingly insufficient tools for detailed codicological studies. Contemporary codicological concepts such as "stratigraphy," "modularity," "booklet," "codicological unit," "circulation" or "production unit," and "usage unit" focus on the manuscript as a layered object collated, deconstructed, and reconstructed over time, taking the artifact in its current physical state simply as a starting point. Collation formulae, on the other hand, represent

brackets. Similarly, additions are represented in brackets in the exponent using a plus sign. The numbers of missing or added leaves can represent either their position in the quire, as in James and Ker's formula, or simply their quantity. The formulae used in modern manuscript catalogs contain many more variations than these, however.

12 J. J. Witkam, Catalogue of Arabic Manuscripts in the Library of the University of Leiden and Other Collections in the Netherlands (Leiden: Leiden University Press, 1982), 10-15; Adam Gacek, Arabic Manuscripts: A Vademecum for Readers (Leiden: Brill, 2009), 71.

13 For a concise history of quire tables, see Bischoff, "Methoden," 13-16.

14 For example, Léon Gilissen, "La composition des cahiers, le pliage du parchemin et l'imposition," Scriptorium 26 (1972): 28-29; Jacques Lemaire, Introduction à la codicologie (Louvain-la-Neuve: Publications de l'Institut d'Études médiévales de l'Université catholique de Louvain, 1989), 51. 


\section{Dorofeeva: Visualizing Codicologically and Textually Complex Manuscripts}

340 | Journal For Manuscript Studies

only the artifact in its current physical state. ${ }^{15}$ On their own, therefore, formulae may be insufficient for representing the layers of construction and possible deconstruction of a particular complex manuscript. In addition, neither collation formulae nor quire tables incorporate an overview of the

15 The concept of the booklet partly inspired Gumbert's definition of a codicological unit, which I have preferred to use here. A booklet, in Pamela Robinson's original definition, is a small but structurally independent production that circulated independently and was only later incorporated into another manuscript: Pamela R. Robinson, “The 'Booklet': A SelfContained Unit in Composite Manuscripts," in Albert Gruijs and J. P. Gumbert, eds., Codicologica 3, Litterae Textuales (Leiden: Brill, 1980), 46-69. See also Orietta Da Rold, "Making the Book: Cambridge, University Library Ii.1.33”, New Medieval Literatures 13 (2011): 275-91 and Alexandra Gillespie, "Medieval Books, the Booklet, and Booklet Theory", English Manuscript Studies 16 (2011): 1-29. For more on the role of quires in manuscripts, see Jean Vezin, "Quaderni simul ligati-recherches sur les manuscrits en cahiers," in P. R. Robinson and Rivkah Zim, eds., Of the Making of Books: Medieval Manuscripts, Their Scribes and Readers. Essays Presented to M. B. Parkes (Aldershot: Scolar P, 1997), 64-72. On codicological units and the stratigraphy of the codex, see J. P. Gumbert, "Codicological Units: Towards a Terminology for the Stratigraphy of the Non-homogeneous Codex," in Edoardo Crisci and Oronzo Pecere, eds., Il codice miscellaneo: tipologie e funzioni: atti del convegno internazionale, Cassino 14-17 maggio 2003 (Turnhout: Brepols, 2004), 25. On production and usage units, see Erik Kwakkel, "Toward a Terminology for the Analysis of Composite Manuscripts," Gazette du livre médiéval 41 (2002): 12-19; idem, "Late-Medieval Text Collections: A Codicological Typology Based on Single-Author Manuscripts," in Stephen Partridge, ed., Author, Reader, Book: Medieval Authorship in Theory and Practice (Toronto: University of Toronto Press, 2012), 56-79. On circulation units, see Marilena Maniaci, "The Medieval Codex as a Complex Container: The Greek and Latin Traditions," in Friedrich and Schwarke, One-Volume Libraries, 27-46; and Patrick Andrist, Paul Canart, and Marilena Maniaci, La syntaxe du codex: essai de codicologie structurale (Turnhout: Brepols, 2013), 59. On modularity, see Marilena Maniaci, "La struttura delle Bibbie Atlantiche," in Marilena Maniaci and Giulia Orofino, eds., Le Bibbie Atlantiche, Il Libro delle Scritture tra monumentalità rappresentazione (Abbazia di Montecassino, 11 luglio-11 ottobre 2000; Firenze, Biblioteca Medicea Laurenziana, 1 marzo-1 luglio 2001) (Milan, 2000): 47-60; and Marilena Maniaci, “Il codice greco 'non unitario.' Tipologia e terminologia," in Edoardo Crisci and Oronzo Pecere, eds., Il codice miscellaneo. Tipologie e funzioni. Atti del convegno internazionale (Cassino, 14-17 maggio 2003) (Cassino, 2004 [Segno e testo 2, 2004]), 75-107. See, in addition, Patrick Andrist, Paul Canart, and Marilena Maniaci, "L'analyse structurelle du codex, clef de sa genèse et de son histoire," in Antonio Bravo García and Inmaculada Pérez Martín, eds., The Legacy of Bernard de Montfaucon: Three Hundred Years of Studies on Greek Handwriting (Turnhout: Brepols, 2010): 289-99. A less recent but still useful work is Marilena Maniaci, Archeologia del manoscritto: metodi, problemi, bibliografia recente, (Rome: Viella, 2002). 


\section{Manuscript Studies, Vol. 4 [2019], Iss. 2, Art. 4}

contents of manuscripts, whose description is usually keyed to page or folio numbers and not to the quiring, a problem already noted by Frank Bischoff. ${ }^{16}$ Texts need to be represented alongside collation, not only because they are often the principal object of study, but also because they are an integral part of the stratigraphy of a manuscript. ${ }^{17}$ Both methods also require some deciphering, often through sketching sets of quire structures on a blank sheet of paper. ${ }^{18}$ The alternative means to such sketches or other schematic representations - which can take up rather a lot of space-is a detailed description, which can also be difficult to visualize. Yet visualizations are often essential, even for an expert audience, to be able to follow an argument that is based on information both about the codicological structures of manuscripts and about their contents-particularly when the manuscripts in question are complex books that may contain different kinds of quires, production and usage units, and types of text. Studies of complex manuscripts

16 Bischoff, "Methoden," 10. As Thom Gobbitt has pointed out to me, in rare cases the location of texts can be described most usefully in terms of quires: for example, if a single manuscript contains a single text across all of its quires except one, which contains another text. This is the case with Paris, Bibliothèque nationale de France, MS lat. 9656, where the entirety of the final quire contains the start of the Lex Salica, while the rest of the preceding manuscript contains the Edictus Langobardorum. When the coincidence of a new text or textual division with a quire break is of codicological significance and merits recording, catalogers (e.g., as Teresa Webber noted, Ker in Medieval Manuscripts in British Libraries) will often already do so as a supplement to the formula.

17 Gumbert illustrates this when he talks about codicological units "enriched" by additions such as glosses: Gumbert, "Codicological Units," 30. The precise placement (especially the beginning and end) of texts within manuscripts also affects how we view their codicological structures, as exemplified by the criticism of Gumbert's terminology in Andrist et al., La syntaxe $d u$ codex, 43 . By pointing out the ways in which possible textual additions complicate the picture, this critique demonstrates how deeply our understanding of the physical makeup of manuscripts (beyond simple mechanical identification of leaf and quire structures) depends on the manner in which they were inscribed with writing: on how this work was planned and carried out, and by whom; and how later additions came to be there. Andrist et al. take this into account in their conceptual framework (p. 60), but its complexity-arising out of the complex possible interactions between texts and their supports-is difficult for nonspecialists to grasp fully, and is another reason to include visualizations in studies of individual manuscripts.

18 Two such sketch methods are shown in Géhin, Lire le manuscrit médiéval, 74-75. 


\section{Dorofeeva: Visualizing Codicologically and Textually Complex Manuscripts}

that do not provide aids of this kind for the reader are difficult to read, and obscure the real interest of the primary material.

These problems have recently been solved by Ad van Els and Sean Curran in their respective $\mathrm{PhD}$ dissertations by incorporating structural diagrams as part of their discussion. ${ }^{19}$ There may be others of which I am unaware. The basic principle of such diagrams, which can be enormously varied and are presented very differently by van Els and Curran, is to show quire structures running down the left-hand side of the page, and their corresponding texts down the right. Such diagrams can be subdivided by production unit, or otherwise adjusted to show those elements of a medieval book that the author wishes to emphasize. As Sean Curran has pointed out to me, this kind of diagram also has the advantage of representing the manuscript as one would read it today, from first to last quire (though not all manuscripts were intended to be read this way, since many were produced quire by independent quire or set of quires; and it may even have been the norm that such quires were not bound together within boards or some other form of cover until years after their production). Since they are illustrations to an argument, structural diagrams are not absolutely essential, but it is difficult to do without them when attempting to discuss in detail the materiality and history of a manuscript composed of quires with multiple missing and added leaves, layers of textual additions, and several stages of quire rearrangement. Structural diagrams also avoid the problem of the different types of quire formulae, each of which will often require transposition into one of the other types depending on the conventions used by the catalog and publisher. For example, publishers and editors of

19 Ad van Els, Een leeuw van een handschrift-Ademar van Chabannes en MS Leiden, Universiteitsbibliotheek, Vossianus Latinus Octavo 15, unpublished PhD dissertation, University of Utrecht (2015): 65; Sean Paul Curran, "Vernacular Book Production, Vernacular Polyphony, and the Motets of the 'La Clayette' Manuscript (Paris, Bibliothèque nationale de France, nouvelles acquisitions françaises 13521)," unpublished $\mathrm{PhD}$ dissertation, University of California, Berkeley, 2013, 28, 42. The first chapter of this dissertation was published as Sean Paul Curran, "Composing a Codex: The Motets in the 'La Clayette' Manuscript," in Judith Ann Peraino, ed., Medieval Music in Practice: Studies in Honor of Richard Crocker (Middleton, WI: American Institute of Musicology, 2013), 219-53. 
Manuscript Studies, Vol. 4 [2019], Iss. 2, Art. 4

English-language books and journals will often require collation formulae taken from German catalogs to be transposed from the type based on the work of Chroust to the type based on the work of Bradshaw. Visual representations of collation, provided they include a key, need not depend on cataloging or other codicological conventions.

\section{The Collation Map}

In the following, I discuss a particular kind of structural diagram, which I shall call a collation map. The aim of this map is to represent an entire manuscript - that is, a set of quires within an existing binding held in a modern library - as it is today, while also visualizing some of the major changes that may have occurred in its material structure over time. It represents an entire manuscript on a single page, providing a "map" of its structure and contents.

The sample manuscripts used here for the collation map are Bern, Burgerbibliothek, MS lat. 611 + Paris, Bibliothèque nationale de France, MS lat. 10756, selected for this purpose because they represent a set of related production units and are structurally and textually complex. ${ }^{20}$ The book was written by several different groups of scribes using Merovingian and pre-Caroline minuscules as well as shorthand (Tironian notes), in six codicologically discrete units, of which folios 116-42 + 145 and folios 143-44 are written on two sets of palimpsested leaves. The Life of St. Sebastian (copied in the seventh century) and the Vulgate Gospel of Mark (copied in the second half of the fifth century) were the subscript texts of these leaves. A quaternio has been removed after folio 72 in the Bern codex and currently occupies folios 62-69 in the Paris codex. As well as being codicologically

20 Léopold Delisle, Inventaire des manuscrits latins conservés à la Bibliotbèque nationale sous les numéros 8823-18613 et faisant suite à la série dont le catalogue a été publié en 1744 (Paris: A. Durand et Pedone-Lauriel, 1863-71), 93. doi:10.5076/e-codices-bbb-0611. 


\section{Dorofeeva: Visualizing Codicologically and Textually Complex Manuscripts}

344 | Journal For Manuscript Studies

complex, the Bern-Paris manuscripts also contain a wide variety of texts and extracts on diverse subjects.

Despite the evidence for the two modern manuscripts having been originally produced as a number of different production units, they can be shown to have originated within the same locality at around the same time, and to have come to form a single book very soon after their production. E. A. Lowe used the dating evidence provided by the computus on folios $94 \mathrm{r}-96 \mathrm{v}$, which states that 5,928 years have passed since the beginning of the world to the present day, making it $727 \mathrm{CE}$, a date which, in his judgment, was "not incompatible with the paleography of the manuscript" (i.e., the manuscript as a whole). Both Lowe and Bernhard Bischoff, who assisted him in drawing up the descriptions for CLA, used the evidence of the Merovingian and early Caroline minuscules found in the manuscript as a whole to date it to within the first three quarters of the eighth century. ${ }^{21} \mathrm{~W}$. M. Lindsay, however, stated that the Bern manuscript was "written, in part at least, before 721," although he did not specify why he thought this. The manuscripts were probably made in east Francia under Corbie influence and are localizable more precisely to Bourges on the basis of one of their formulae (see Appendix, text 12b). ${ }^{22}$

The collation of the Bern-Paris manuscripts is expressed below using a collation formula, a list of production units, and a more precise itemization of the quires in unit III. Information about their collation has been taken

21 E. A. Lowe, Codices Latini Antiquiores: A Palaeographical Guide to Latin Manuscripts Prior to the Ninth Century, 11 vols. (Oxford: Clarendon, 1934-66). Bern, Burgerbibliothek, MS lat. 611: CLA VII.604a-e and VII.866-87, with a bibliography on p. 55; Paris, Bibliothèque nationale de France, MS lat. 10756: CLA V.604. Bernhard Bischoff, Katalog der festländischen Handschriften des neunten Jabrhunderts (mit Ausnabme der wisigotischen), ed. Birgit Ebersperger (Wiesbaden: Harrassowitz, 1998), 131.

22 Zeumer identified it as one of three Burgundian manuscripts containing formularies, but it should be noted that Bourges is in Centre-Val de Loire rather than Burgundy. The other two manuscripts are Paris, Bibliothèque nationale de France, MS lat. 4629, and Leiden, Universiteitsbibliotheek, BPL 114. Karl Zeumer, ed., Formulae merowingici et karolini aevi accedunt ordines iudiciorum dei (1886; Turnhout: Brepols, 2010), 166. 
Manuscript Studies, Vol. 4 [2019], Iss. 2, Art. 4

from the e-codices description of the Bern manuscript, written by Florian Mittenhuber, Gerald Schwedler, and David Ganz:

Collation formula: ${ }^{23}$

$1^{6+2}$ ( 1 leaf after 2 and 1 leaf after 5$)+2^{6+2}$ (1 leaf after 2 and 1 leaf after 5$)+3^{2+1}$ (leaf 1 is sewn separately onto leaf 2 using a stub fold) $+4^{8-1}$ (missing leaf 5$)+5^{8}+6^{6+1}$ (added leaf 1 glued to leaf 7 due to broken stub fold) $+7^{8}+8^{8}+9^{8+1}$ (leaf 9 attached to leaf 8 of previous quire, but belongs to this quire) $+10^{6}+11^{6}+12^{8}+13^{6+1}$ (leaf 3 a singleton) $+14^{6}+15^{8}+16^{6}+17^{2}+18^{8}+19^{8}+20^{8}+21^{2}+22^{4}+23^{8}$.

Production units: $:^{24}$

I: folios 1-19 (quires 1-3)

II: folios 20-41 (quires 4-6)

III: folios 42-93 (quires 7-13; a single quire, originally located after folio 72, is now bound in Paris, Bibliothèque nationale de France, MS lat. 10756)

IV: folios 94-115 (quires 14-17)

V: folios 116-145 (quires 18-22)

VI: folios 146-153 (quire 23)

Mittenhuber, Schwedler, and Ganz noted that unit III contains quire numbers: I (fol. 49v), II (fol. 57v), III (fol. 65v), and VIII (fol. 86v). The Paris

23 The information provided in the e-codices description has here been reformulated to correspond with the conventions employed by Bradshaw and Ker. The original formulation on e-codices is as follows: " $2(\mathrm{III}+2)^{16}[\mathrm{f} .3$ und 6, 11 und 14 sind Einzelblätter $]+(\mathrm{I}+1)^{19}[\mathrm{f} .17$ ist gefalzt, an f. 18 angehängt, aber separat geheftet $]+(\mathrm{IV}-1)^{26}$ [rechte Hälfte des innersten Doppelblattes fehlt $]+\mathrm{IV}^{34}+(\mathrm{III}+1)^{41}$ [Ansetzfalz von f. 35 abgebrochen, klebt an f. 41] $+2 \mathrm{IV}^{57}+$ $(\mathrm{IV}+1)^{66}[\mathrm{f} .66$ ist mit Falz an f. 57 fixiert, gehört aber zur folgenden Lage $]+2 \mathrm{III}^{78}+\mathrm{IV}^{86}+$ $(\mathrm{III}+1)^{93}\left[\right.$ f. 89 einzeln] + III ${ }^{99}+\mathrm{IV}^{107}+\mathrm{III}^{113}+\mathrm{I}^{115}+3 \mathrm{IV}^{139}+\mathrm{I}^{141}+\mathrm{II}^{145}+\mathrm{IV}^{153}$.”

24 These have been identified as separate principally on the basis of their mise-en-page, including ruling and the dimensions of the written space. For more information, see the e-codices description. 
quire also belongs to this group, as it bears the number VI. Unit III was therefore originally constructed as follows according to its early medieval quire numbers (the quire numbers of the collation formula are given in brackets):

\section{Quire no. Folios}

I $\left(7^{8}\right): \quad 42-49$

II $\left(8^{8}\right): \quad 50-57$

III $\left(9^{8+1}\right): \quad 58-65$ (fol. 66 was therefore added after the quires were numbered but before the text was copied, as there is no textual break)

IV $\left(10^{6}\right): \quad 67-72$ (final leaf now missing)

V: $\quad$ Missing

VI: $\quad$ Paris quire

VII $\left(11^{6}\right): \quad 73-78$ (first and final leaves and their text now missing)

VIII $\left(12^{8}\right): \quad 79-86$

The collation, production parts, and idiosyncrasies of the Bern-Paris manuscripts are difficult to understand simply from this summary, no matter how clearly one indicates the numbers and explains the reasoning behind them. Most if not all readers will have treated the above as a theoretical exercise, trusting that the catalogers and author have got their collation right, since the working-out is laid out for anyone with pencil and paper to check. There is no question, with such a complicated physical structure, of showing how it corresponds with the texts, except in detailed analyses of each separate production unit.

The collation map in figure 1 is a way out of these problems. From this diagram, it should be immediately clear which quires correspond with which codicological units, and how they are structured; how the texts are distributed within the codex; and the original location of the section now bound into another manuscript. The collation map is laid out on two levels: the codicological level on top, shown in the quire diagrams (whose boxed appearance is based on the quire diagrams used by Thom Gobbitt to show from which side-recto or verso-the leaves were pricked and ruled); and the textual level on the red line below, which maps the texts relative to their 
Manuscript Studies, Vol. 4 [2019], Iss. 2, Art. 4

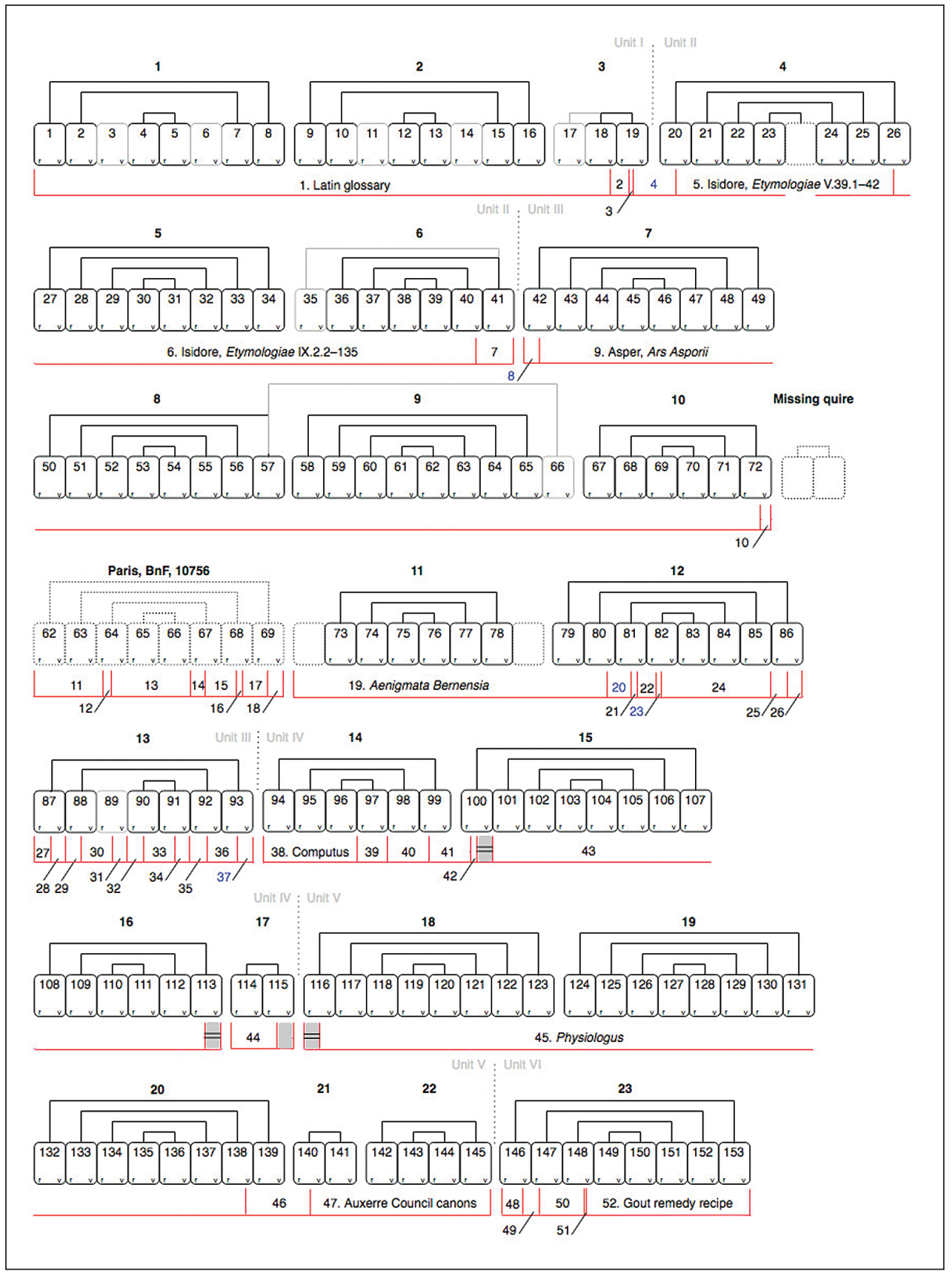

FIGURE 1. Collation map of Bern, Burgerbibliothek, MS lat. 611. 
location on the quire diagrams. ${ }^{25}$ For this collation map, the texts have been numbered in accordance with the Appendix, but a numbered text key may also be attached as part of the diagram. The map itself was drawn using the online program draw.io, which is simple to use, but it can be replicated using any other software that permits users to work freely with geometrical figures alongside text. The various elements of the map represent the following:

\section{Codicological level}

Black lines Leaves and quires present in the manuscript as currently bound, and which of the leaves are conjugate.

Dotted lines Leaves or quires not present in the manuscript as currently bound. The dotted lines can represent different amounts of data, from a simple observation of absence to full information (if available, as with quire 11) about quire structure and contents. Where a full quire is missing and no information about it is available, it is represented as a bifolium.

Note: Where leaves are evidently missing, it is impossible to indicate whether or how they were conjugate pairs and hence also where the spine-fold fell, through which the leaves would have been sewn.

Gray lines Added leaves and the folds by which they are attached to quires.

Note: In the case of quires 1, 2, and 13 in figure 1, it is unclear from the codicological description how the added leaves are attached, and the lines representing the folds are therefore missing.

r or v Recto or verso; can be replaced with " $h$ " and "f" for "hair" and "flesh," if preferred.

25 Thomas Gobbitt, Lombard Law-Books, 1025-1125: The Liber Papiensis in Manuscript Context (Leeds: Kismet Press, in preparation). 
Manuscript Studies, Vol. 4 [2019], Iss. 2, Art. 4

Textual level

Red line Horizontal line: represents the text. Where the horizontal line under a missing leaf is interrupted and the text is the same (as in quire 4), it shows that the missing leaf was blank. Where the horizontal line under a missing leaf is uninterrupted and the text is the same (as in quire 11), it shows that the missing leaf contained writing, and that the text is incomplete.

Vertical lines: represent the transition from one text to another. Where a line aligns with the edge of a leaf box, the text transition coincides with the transition from one leaf to another. Where a line aligns with the center of a leaf box, the text transition coincides with the transition from the recto to the verso of that leaf. Where a line is not aligned with an edge or the center of a leaf box, the text transition occurs on the recto or verso of that folio.

Other colors Texts added after the main text was copied. In figure 1, these are represented in blue.

Gray box Blank leaf. A double horizontal line through a gray box indicates that the leaf was ruled.

It should be noted that in the collation map, the manuscript represented is Bern, Burgerbibliothek, MS lat. 611, rather than Bern, Burgerbibliothek, MS lat. 611 + Paris, Bibliothèque nationale de France, MS lat. 10756. The Paris quire is depicted in the Bern manuscript as a missing element about which we have full information (because it is extant elsewhere). This is an important distinction because it means that the quire numbering in the collation map is that of the Bern manuscript. A manuscript in this sense is a set of quires bound together and cataloged under one classmark in a modern library. Since the collation map represents the evolution of a single medieval manuscript over time, it must therefore be based on a single manuscript. This means that, in cases where a single codicological unit or a related set of production units is now divided across two or more manuscripts, one of 


\section{Dorofeeva: Visualizing Codicologically and Textually Complex Manuscripts}

these manuscripts-preferably the one with the most quires-must be selected as the subject of the collation map. It is possible to map the evolution of the single codicological unit or set of production units instead, but in that case the quires must be numbered according to their medieval arrangement. The collation map will then no longer reflect an existing manuscript, but rather the idea of a manuscript as it might have been in the past. This is generally to be avoided, since it introduces too much conjecture, or it should be restricted to the analysis of the manuscript rather than to its description.

The collation map in figure 1 does not depict all possible codicological features, but these can be introduced and their function described in the text or in an added key. An example of such a feature is a quire that, due to a past mis-binding, now occupies a position several quires removed from its original location. Such a quire can be represented using dashes, with both its original and current locations reflected in the quire numbering, or a special symbol can be introduced in its original location to indicate its current location. Similarly, although figure 1 does not show that the Bern manuscript has palimpsest folios of different dates (fols. 116-42 and 145, and fols. 143-44), they could be indicated using a different color or by shading or otherwise texturing the corresponding leaf boxes. The collation map can represent these and other features flexibly, depending on what the researcher wishes to show.

The collation map has two important functions in addition to visualization. The first is to avoid making a judgment about the structure of quires that contain singletons in the place of whole bifolia (as is the case with leaves 3 and 6 in quires 1 and 2). This is unavoidable with collation formulae, like those of N. R. Ker, that take bifolia as the basis of quires. Ker would list an eight-leaf quire with singletons in place of a single bifoliuma conjugate pair of leaves-as a quaternio and not a ternio, but only in those circumstances where the two singletons were from the outset positioned within the quire as an alternative to a conjugate pair of leaves. As Gumbert (who referred to singletons used in such a way as "coupled leaves") observed, this strategy (perhaps an economical means to make use of sheets too small to form a bifolium) was necessarily avoided for the outermost and innermost 
Manuscript Studies, Vol. 4 [2019], Iss. 2, Art. 4

pairs of leaves in a quire. ${ }^{26}$ As Gumbert also noted, however, we do not know the precise extent of this replication practice in the Middle Ages, and perhaps more problematically, not all catalogers adopt this principle. We see this from the first two quires in Bern, Burgerbibliothek, MS lat. 611, which are listed on e-codices as ternios with two additional leaves rather than as quaternios, although these additional leaves may be coupled pairs in Ker's and Gumbert's terms. In the collation map, we see the placement of the additional leaves in place of a bifolium and the overall number of leaves in the quire, but we do not need to label the quire a quaternio or a ternio. The question raised by collation formulae of how to treat conjugate pairs of leaves is valuable in that it refers us back to the medieval production process, but it does highlight the sometimes theoretical nature of formulae. To label an eight-leaf quire with a pair of conjugate leaves either as a quaternio or as a ternio with two added singletons is to say of the manuscript makers "they conceived this quire as a quaternio" or "they conceived it as a ternio." There are very interesting conceptual codicological implications to this, not least that such labels approach the idea of the "ideal copy" suggested by Fredson Bowers for printed books, where one records the correct form and then any deviations from it. ${ }^{27}$ But they are ultimately not especially relevant to the discussion of any single manuscript, where it is much more important simply to establish the number and relationship of leaves in each quire. In the Bern manuscript, quire 1 looks the same both in the physical book and in the collation map regardless of what label it is assigned by the cataloger.

The second important function of the collation map is to highlight features of interest or problems arising from the codicological description, and to indicate codicological uncertainty. Certain features can sometimes only

26 Gumbert, "Skins, Sheets and Quires," 88. An example of Ker's use of conjugate leaves in his collation formulae can be found in Ker, Catalogue, xxii, as remarked by Teresa Webber (Cambridge Palaeography Workshop, 25 May 2018). See also note 7 above.

27 Bowers, Principles, 113-23, 404-6. For a discussion of the bibliographical principles of the ideal copy, and on the terminology used by descriptive bibliography generally, see Dane, Abstractions of Evidence, ch. 5 . 


\section{Dorofeeva: Visualizing Codicologically and Textually Complex Manuscripts}

be discovered from the collation map. In the case of the Bern manuscript, the map reveals an inconsistency in the online collation formula, which lists quire 11 as a ternio. The manuscript's list of contents explains, however, that the textual loss from the riddles means the quire is missing two leaves at the beginning and end. ${ }^{28}$ Such a loss makes the quire originally a quaternio, or a ternio with two added leaves, the original presence of lost leaves usually being signaled in the e-codices collation conventions. Here again we have the question of how to categorize the quire, which would need to be answered before a collation formula could be created, and which the collation map bypasses entirely as inconsequential for the physical structure of this particular book. The failure to record the lost leaves in the collation formula only becomes apparent during the process of mapping the text against the quire structures on the collation map. Furthermore, text 4 (a birth lunarium) is listed on e-codices as a later addition. By mapping the text onto the manuscript structure, we can see that codicological units 1 and 2 must have been joined at the time this added text was copied-that is, in the ninth century. This is of particular interest for the history of this manuscript, especially when one attempts to reconcile its current contents with its original contents (listed in text 36 in the Appendix) and therefore with its original quire order. Finally, unlike formulae, the collation map can represent codicological uncertainty flexibly but transparently-as with the unclear relationship of leaves 3 and 6 in quire 1, or with any other structural codicological feature, which it can be adapted to represent.

To summarize, this kind of diagram is convenient for four main reasons. First, the collation map provides an instant overview of the length and distribution of texts between quires. Some manuscripts have a very complex history and quire collation; reference to this kind of diagram during a discussion of the manuscript's contents makes the argument easier to follow. Second, it provides a visual representation of the manuscript's overall structure at a glance. Third, it is easier to read and understand than the collation formula on its own, and it is a useful working aid when examining digital

28 "Der Text ist unvollständig (vor f. 73 sind das erste Blatt, nach f. 78 das letzte Blatt von Lage 7 ausgefallen)," available at https://www.e-codices.unifr.ch/en/description/bbb/0611/ Mittenhuber. 
Manuscript Studies, Vol. 4 [2019], Iss. 2, Art. 4

manuscripts, whose quire structures cannot be determined by looking at their spine-folds and sewing as readily as they can in the physical book. For such digital manuscripts, the collation map allows the codicologist systematically to map the physical structure from the catalog, and the contents against it, highlighting any discrepancies or points of interest before beginning an in-depth study. This is an important consideration in light of the continually growing number of digital manuscript repositories, which significantly reduce the need for manuscript scholars to travel to archives. ${ }^{29}$ And finally, the collation map avoids prescribing a set of standards, instead aiming to provide an easily comprehensible and concise means of visualizing manuscripts as whole books.

\section{The Collation Map and the Digital Sphere}

Visualizations like the collation map are an important supplement to the collation formula (as well as quire tables). There are two particular reasons for this: first, the rapid pace at which libraries and archives are digitizing their holdings, and second, the development of new digital tools. A wide range of such tools is now available, from paleographical transcription aids such as T-Pen, Transkribus, and Rescribe, to methods for working with the contents and structure of whole manuscripts, including TEI and VisColl. More sophisticated technologies such as Archetype (based on DigiPal), a digital framework for displaying, marking up, and analyzing digitized images, are also appearing. Some of these tools have existed for some time, while new ones are being developed. Digital paleography and scholarly editing of texts, undertaken by Peter Stokes and others (see, for example, the use of Graphoskop by Maria Gurrado and Giancarlo Lestingi, and the Scripta project at Université Paris Sciences et Lettres), as well as international projects

29 These include both the growing digital collections of individual libraries or archives, such as the Gallica service of the Bibliothèque nationale de France, and major national repositories such as the Virtual Manuscript Library of Switzerland (e-codices). The Digitized Medieval Manuscripts app (DMMapp) at digitizedmedievalmanuscripts.org provides a regularly updated list of these numerous repositories worldwide. 


\section{Dorofeeva: Visualizing Codicologically and Textually Complex Manuscripts}

\section{Journal For Manuscript Studies}

such as HIMANIS and DiXiT, are also moving manuscript studies into the digital sphere. ${ }^{30}$ Increasingly sophisticated methods for the large-scale evaluation of digital manuscript facsimiles, such as recently developed graphical models for computer-aided analysis of cartularies, are now available. ${ }^{31}$ Similar, collaborative initiatives are taking place in the library sector, with the recent implementation of the International Image Interoperability Framework (IIIF) and the formation of the ISMI project to create international stable manuscript identifiers at the IRHT-CNRS. There is still a long way to go: digital manuscript studies face questions of sustainability-in terms of which the digital medium offers an advantage, but also significant vulnerabilities - and digital facsimiles cannot wholly replace the original manuscript for scholarly work at the present level of technology. But it is evident that manuscript studies are moving very swiftly into the digital sphere, not least because the public accessibility of the above sources and tools makes it much easier to verify and discuss manuscript-based research. These digital developments mean that diagrams such as the collation map are continuously becoming easier to create and are much more suitable for screen-based manuscript work than more traditional means of working out and representing collation. This is already suggested by the existence of VisColl, the manuscript collation visualization tool built by Dot Porter and the Manuscript Collation Project team at the Schoenberg Institute for Manuscript Studies. ${ }^{32}$ This free tool, hosted on GitHub, combines both digital and traditional collation methods by allowing users to create a collation visualization alongside a collation model and image list. ${ }^{33}$ The collation model enables users to depict the individual quires in a manuscript, their foliation and structure.

30 Graphoskop: palaeographia.org/graphoskop. Scripta project: scripta.psl.eu. HIMANIS: himanis.hypotheses.org. DiXiT: dixit.uni-koeln.de.

31 Julio Escalona, Cristina Jular Pérez-Alfaro, and Anna Bellettini, “Two Graphical Models for the Analysis and Comparison of Cartularies,” Digital Medievalist 10 (2016). doi:10.16995/ dm.55.

32 Schoenberg Institute for Manuscript Studies: schoenberginstitute.org. See also Dot Porter, Alberto Campagnolo and Erin Connelly, "VisColl: A New Collation Tool for Manuscript Studies," in Hannah Busch, Franz Fischer and Patrick Sahle, eds., Codicology and Palaeography in the Digital Age 4 (Books on Demand GmbH, 2017), 81-100.

33 GitHub website, github.com/leoba/VisColl. 
Manuscript Studies, Vol. 4 [2019], Iss. 2, Art. 4

On the basis of the collation model and a user-uploaded set of manuscript images, VisColl then creates a diagrammatic visualization that displays quires as sets of bifolia next to their manuscript images. The user is also able to convert the model automatically into two different types of collation formulae. A more flexible and sophisticated beta version of VisColl is in development, and it may help advance the usability of manuscript visualizations to a new level. ${ }^{34}$ In addition, it may soon be possible to use VisColl for automatic generation of the collation map presented here.

\section{Conclusions}

The collation map cannot contain all possible information about the physical manuscript and its contents. It does not, for example, visualize damage of various kinds to parchment leaves, and it cannot easily show different kinds of marginalia, layers of annotation, or differences in page layout and ruling patterns. Such information can be evidence that contributes to interpreting the stratigraphy of complex manuscript structures. For such visualizations of the parchment leaves of a medieval book, it is necessary to use schematic diagrams of individual quires. The same applies to studies of production and circulation units, whose relationships can be very complex and thus easier to represent using conceptual diagrams rather than the collation map. ${ }^{35}$ It is also not necessarily useful for codicologically and textually simple manuscripts, where a diagram of a single representative quire may be sufficient as a visualization. Within these limitations, however, the diagram is flexible, and adaptable to emphasize details of particular interest to the codicologist. Most importantly, it provides an accessible means of

34 For a full report on the possibilities of the new version of VisColl, see Alberto Campagnolo, Dot Porter, Erin Connelly, Doug Emery, and Dennis Mullen, "Virtually Disbinding Codices: Visualization of the Construction of Codex Textblocks," in Matthew James Driscoll, ed., Care and Conservation of Manuscripts 16. Proceedings of the Sixteenth International Seminar Held at the University of Copenhagen 13th-15th April 2016 (Copenhagen: Museum Tusculanum, 2018), 77-90. doi:10.5281/zenodo.1219180.

35 See, for example, the conceptual diagrams in Andrist et al., La syntaxe du codex, e.g., on p. 71. 
combining the basic codicological and textual information-quire structure and contents-about a manuscript, which can then be used as the visual and reference basis for a full study. In an increasingly digital and international environment, visual representation and non-reliance on national systems are crucial aids to scholarship.

The collation map is therefore meant principally as a practical tool, permitting the user to juxtapose information conventionally recorded separately in a catalog description. In particular, the collation map renders the layered nature of a complex medieval manuscript comprehensible during the initial codicological study as well as to the reader of the resulting publication. It is part of the work of codicologists to establish the order of quires and the irregularities in their composition, and collation formulae are an important conceptual as well as practical instrument for this, but the order and composition of quires in Western medieval manuscripts also have direct bearing on each manuscript's method of production, provenance, internal textual relationships, and other complex questions. The collation map discussed here enables manuscript scholars working with heterogeneous codices to visualize these features, to record the ways in which they interact, and to highlight shifts from one context to another. In doing so, the map promotes our understanding of the manuscript book as a coherent whole.

\section{Acknowledgments}

I am very grateful to Teresa Webber for her comments and advice on draft versions of this article. My thanks also go to Thom Gobbitt, Rutger Kramer, and Erik Kwakkel. 
Manuscript Studies, Vol. 4 [2019], Iss. 2, Art. 4

Dorofeeva, Visualizing Complex Manuscripts

\section{Appendix: Contents of Bern, Burgerbibliothek, MS lat. $611+$ Paris, Bibliothèque nationale de France, MS lat. 10756}

The appendix is based on my doctoral dissertation, incorporating information from the description accompanying the digitization on e-codices by Florian Mittenhuber, Gerald Schwedler, and David Ganz. ${ }^{36}$

\section{Bern, BurgerbibliotheK, MS LAT. $611^{37}$}

1. 1ra-18va: Latin glossary "Abba” (D-Z).

2. 18va-19rb: Latin glossary $(\mathrm{A}-\mathrm{H})$.

3. 19r: Names (some upside down) in a darker ink and pre-Caroline hand of men who gave (dederunt) or didn't give (non) something.

4. $19 \mathrm{v}-20 \mathrm{r}$ : Birth lunarium. Addition of s.ix $\mathrm{x}^{3 / 3}$.

5. 20v-26r: Isidore of Seville, Etymologiae V.39.1-42, De descriptione temporum.

6. 26r-40v: Isidore of Seville, Etymologiae IX.2.2-135, De gentium uocabulis.

7. 40v-41v: Palladius of Hellenopolis (Paradisus), Historia Lausiaca 32.1-13 (Pachomius and the Tabennesiots). Later addition.

8. 42r: Poem on the winds. Later addition.

9. 42v-72v: Asper, Ars Asporii.

10. 72v: Isidore of Seville, Etymologiae I.22.1-2. On Tironian notes. Contemporary note in the left margin under Roman numeral II (referring to list of contents on 92v): "Lucius Annius Senica qui notas conposuit de Grecis fuit et magister Neronis imperatoris erat." Incomplete due to loss of final quire leaf.

Paris, Bibliothèque nationale de France, MS Lat. $10756^{38}$

11. 62r-64r: Formulary (Formulae Bituricenses) with five documents pertaining to the legal exchange of goods, gifts, and land, with Tironian notes in the lower margins of folios $62 \mathrm{r}-63 \mathrm{r}$.

12. 64r: a. Jerome, Contra uigilantium ch. XIV in Tironian notes (five-line excerpt). On the rectitude of sending alms to monks in the Holy Land.

b. Formula of a mandate to register a donation in Bourges (not listed on e-codices).

36 Anna Dorofeeva, "The Reception and Manuscript Context of the Early Medieval Latin Pre-bestiary Physiologus," PhD thesis, University of Cambridge, 2015. See also David Ganz, "In the Circle of the Bishop of Bourges: Bern 611 and Late Merovingian Culture", in Stefan Esders, Yaniv Fox, Yitzhak Hen, and Laury Sarti, eds., East and West in the Early Middle Ages (Cambridge: Cambridge University Press, 2019): 265-80.

37 Digitized manuscript doi:10.5076/e-codices-bbb-0611.

38 Digitized manuscript identifier: ark:/12148/btv1b9065920c. 


\section{Dorofeeva: Visualizing Codicologically and Textually Complex Manuscripts}

\section{8 | Journal for Manuscript Studies}

13. $64 \mathrm{v}-66 \mathrm{v}$ : Table of a nineteen-year lunar cycle.

14. $66 \mathrm{v}-67 \mathrm{r}$ : Description of a nineteen-year lunar cycle, attributed to Victorius of Aquitaine.

15. $67 \mathrm{v}-68 \mathrm{r}$ : Verses on the creation and end of the world, mainly in Tironian notes.

16. $68 \mathrm{v}$ : Birth lunarium of thirty days. First line partially trimmed away.

17. 68v-69r: Dionysius Exiguus, Argumenta paschalia (argument 16 on the rationale of the leap day). Ends with two lines on $69 r$, the remainder of which is blank and unruled.

18. 69v: Gregory I, Regula pastoralis III.12 (= Taio: Sententiae III.52). In Tironian notes.

\section{Bern, Burgerbibliothek, MS LAT. 611}

19. 73r-80v: Latin aenigmata, known as Aenigmata Bernensia. Incomplete due to loss of first and last quire leaves (before fol. 73 and after fol. 78). A Greek alphabet with corresponding letter-names and Latin phonemes has been written into the bottom margins of folios $77 \mathrm{v}-78 \mathrm{r}$ in a contemporary hand; underneath it is a Latin alphabet with numbers assigned to each letter.

20. $80 \mathrm{v}-81 \mathrm{r}$ : Metrical sentences, arranged alphabetically (A-T), partly in Tironian notes. Later addition. Remainder of page blank.

21. 81v: List of measurements for Noah's Ark. In uncial.

22. 81v-82r: Isidore of Seville, Etymologiae XV.16.2-3. List of various measurements and how they fit into the stade (stadium).

23. 82r: Excerpt from Jerome, In Danielem 10:12-14. Later addition.

24. 82v-85v: Pseudo-Galen, Epistula de febribus.

25. 86r: a. Jerome, In Danielem V.19b (excerpt).

b. Taio of Saragossa, Sententiae II.37 (excerpt).

26. 86v: Three epitaph formulae for abbesses. Traces of two lines of Tironian notes in a darker ink visible in bottom margin.

27. 87r: Prognostics for a good or bad summer or winter (7 lines) in Tironian notes. The remainder of the page left blank.

28. 87v: Jerome, extracts (among them In Matthaeum V.12.42-43, 29, 30; VII.14; X.26, 29, 37; XIII.31, 33; XVI.27; XX.25; XXII.18, 34; XXV.11; In Ionam II.2; Epistula 123,14), of which a few words are written in Tironian notes.

29. 88r: a. Anonymous compilation of questions and answers on grammar, in 18 lines of Tironian notes.

b. Taio of Saragossa, Sententiae, verse epigram.

b. Taio of Saragossa, Sententiae, prologue (end).

30. $88 \mathrm{v}-89$ r: Sacramentarium Gelasianum I.36, preface to the Lord's Prayer. Ends in 4 lines of Tironian notes.

31. $89 \mathrm{v}$ : a. Most of the In aurium apertione Lent service for the induction of catechumens. Mostly in Tironian notes. Listed as "Alcuinus incertus: Disputatio praeviorum ch. 9" on e-codices. 


\section{Manuscript Studies, Vol. 4 [2019], Iss. 2, Art. 4 \\ Dorofeeva, Visualizing Complex Manuscripts}

b. Gregory I, Moralia in Iob XII.52 (= Taio of Saragossa, Sententiae III.54) (4 lines) followed by his Regula pastoralis III.11 (= Taio of Saragossa, Sententiae III.28)

(2.5 lines) and Moralia in Iob XIV.52 (= Taio of Saragossa, Sententiae III.44) (1.5 lines).

32. 90r: a. Gregory I, Regula pastoralis III.4 (= Taio of Saragossa, Sententiae II.44) (7 lines).

b. Isidore, Sententiae III.57.1-4, 6-7.

33. 90v-91r: Excerpts from Jerome (In Isaiam XVI.58, 66), Isidore (Etymologiae VI.19.63) and Augustine (Enarrationes in Psalmos 96.15), almost entirely in Tironian notes.

34. 91v: Unidentified homily on penitence. Begins with text from Julianus Pomerius, De uita contemplatiua II.7.6, III.29. Largely in Tironian notes.

35. 92r: Unidentified homily, mostly in Tironian notes after the first five words. Contains quotations from Amos and Zacharias, among others, and in the middle excerpts from Taio of Saragossa, Sententiae III.34-35.

36. 92v-93r: Original contents list to the manuscript. Six lines of text have been added to the bottom of $92 \mathrm{v}$ from Gregory I, Moralia in Iob V.22, on the ant-lion. A gap has been left on 93r between item XV (“Ad archepresbyterum instituendum”) and item XVI ("Quid sanctus hieronimu [sic] de antidotis dixit").

37. 93v: Isidore of Seville, De natura rerum, wd diagram. Probably intended to accompany the poem on the winds on folio $42 \mathrm{r}$ and may be a later Carolingian addition. Remainder of page left blank, with the exception of some scratches: a four-square grid, and the word "ggehana" (?).

38. 94r-96v: Computus, given in dialogue form, based on the table of Victorius of Aquitaine.

39. $97 \mathrm{r}^{-} \mathrm{v}$ : Isidore, De ecclesiasticis officiis I.11.4-12.7.

40. 98r-99r: Gregory I, epistola IX.213 to Brunhilde on the ordination of laymen as bishops.

41. 99r-100r: Gregory I, Dialogues IV.25, 33.424, 34.83.9, 50; on purgatory.

42. 100r: Moralia in Iob XVIII.54 (see also Taio of Saragossa, Sententiae I.38). Begins on line 5).

100v: Blank, ruled.

43. 101r-113r: Pseudo-Methodius, De initio et fine saeculi (The Apocalypse). Last page ends with three lines of text and one line of pen trials, and is otherwise blank and ruled.

113v: Blank, ruled.

44. 114r-115r: Jerome, Epistula de uirginitate seruanda ad Eustachium (ch. 30).

Inc. "In epistula sancti hyeronimi presbyteri ad eustochium."

115v: Blank, unruled. Traces of two lines of text visible.

116r: Blank, ruled.

45. 116v-138v: Physiologus in forty chapters (Y version).

46. 138v-140r: Twenty-two Greek and African church canons on the election of bishops (the Collectio Bernensis). 
47. 140v-145v: Canons of the Council of Auxerre (c. 573), ch. 1-42. From 144r, 1. 11, there is a different, unidentified ending, perhaps compiled from individual excerpts.

48. 146r'v: Quintus Gargilius Martialis, Medicinae ex oleribus et pomis, 72-97. Title in uncial.

49. 146v-147r: Dynamidia II.9-10, on the medicinal properties of various agents.

50. $147 \mathrm{r}-148 \mathrm{v}$ : Remedy recipes (e.g., for headaches and gout). Possibly also derived from the Dynamidia.

51. 148v: Pseudo-Oribasius, Commentaria in aphorismus Hippocrati. Prologue.

52. 148v-153v: Recipe for a gout remedy. Possibly also derived from the Dynamidia. 


\section{List OF MANUSCRIPTS CITED}

Aberdeen, University of Aberdeen

MS 24: 209 n. 38, 220 n. 62, 221 n. 64, 221, 221 n. 65

Ann Arbor, University of Michigan, Special Collections Library

MS Leaf 38: 320

Baltimore, Walters Art Museum

MS W. 8: 251

MS W. 105: 187-8, 187-8 n. 1, 188 n. 2, 189 fig. 1, 190-2, 191 n. 6, 191 n. 7, 191 n. 8,192 n. 11,193 fig. 2, 194 fig. 3, 195 fig. 4, 196, 199, 201, 203, 205, 208-11, 213, 216-20, 219 fig. 12, 222-30, 222-3

n. 70, 223 fig. 13,226 fig. 14

Berlin, Staatsbibliothek

MS Or. fol. 1211: 249 n. 33

Bern, Burgerbibliothek

MS lat. 611: 335, 337-8, 343-46, $344 \mathrm{n}$. 21, 344 n. 22,345 n. 23,345 n. 24,347 fig. 1, 348-52, 352 n. 28, 357-60, 357 n. 36,357 n. 37

Cairo, Karaite Synagogue

Gottheil 14: 245-6, 246 fig. 7, 249 n. 30, 264

Gottheil 17: 237, 237 n. 12

Gottheil 34: 231 n. 2, 248-9, 248 n. 27, 248 n. $28,257-8$ n. 56,260 n. 64,264

Cambridge, Cambridge University Library MS Gg. 1.1: 390-1, 390-1 n. 2, 391 n. 3, 391-2 n. 4, 392 fig. 1, 397 n. 9

MS Ii. 1.33: 340 n. 15
Cambridge, Trinity College

MS F. 12.70: 267

MS F. 12.71: 267

Chantilly, Musée Condé

MS 9: 298-9 n. 76

Cleveland, Cleveland Museum of Art, The Jeanne Miles Blackburn Collection 2011.51 fol. 390 : 303, 328, 331 n. 96

Columbus, The Ohio State University

Libraries, Rare Books \& Manuscripts

Library

Spec.Rare.MS.MR.Frag.74: 271-286, 271 n. 4,273 n. 7, 273 n. 8, 274 n. 10, 274 n. 11, 275 n. 12, 276 n. 13, 275 n. 14, 276 n. 16, 276 n. $18,276-7$ n. 19,277 n. 20,277 n. 21,277 n. $22,277-8$ n. 23,278 n. 24 , 279 n. 25,279 n. 26,280 n. 27,280 n. 28 , 280 n. 29,281 n. 30,281 n. 31,281 n. 32 , 286 n. 43, 286 n. 44,286 n. 45, 287 fig. 1 , 288-309, 289 fig. 2, 290 fig. 3, 290 n. 50, 290 n. 51,290 n. 52,291 n. 53, 292 n. 55, 292 n. 58, 293 fig. 4, 296 n. 66, 296 n. 69, 297 n. 70, 297 n. 71, 298 n. 74, 299 n. 77, 299 n. 78, 299 n. 80,300 fig. 5, 301 fig. 6, 303 fig. 7, 304 n. 84, 306 fig. 8, 310-31, 310 n. 89,311 n. 90,331 n. 92

Copenhagen, Kongelige Bibliotek Cod. Heb. II: 236, 236 n. 9, 266

Cod. Heb. III: 268

Cod. Heb. IV: 268

Dublin, Trinity College Library MS 16: 239 n. 14 


\section{Dorofeeva: Visualizing Codicologically and Textually Complex Manuscripts}

\section{4 | Journal for Manuscript Studies}

MS 94 (F.5.21): 191-2, 192 n. 9

MS M 2.5: 268

Frankfurt-am-Main, Stadtbibliothek olim Ausst. 4: 236, 236 n. 9

Genoa, Biblioteca Universitaria MS D.IX.31: 268

Ghent, Universiteitsbibliotheek Gent MS 92: 334 n.1

Hamburg, Staats- und Universitätsbibliothek

Cod. Hebr. 45: 242 n. 19

\section{Haverford, Haverford College}

Rendel Harris 1: 242-3, 242 n. 19, 262, 262 n. 66,265

Iowa City, University of Iowa Special

Collections xMMs.Br2: 410-1, 411 fig. 6 xMMs.Ps3: 409-11, 411 fig. 6 xMMs.Se1: 410-1, 411 fig. 6

Istanbul, Karaite Synagogue Istanbul Pentateuch: 237, 237 n. 12

Jerusalem, National Library of Israel MS Heb 4ำ90: 233-4, 234 n. 6, 238 fig. 4, 242, 242 n. 19, 265

MS Heb 4¹112: 265

MS Heb 45147: 237, 237 n. 12

MS Heb 86527: 236 n. 7

Kraków, Biblioteka Jagiellońska MS 1599 (DD.VI.1): 368

Kremsmünster, Stiftsbibliothek

Kremsmünster CC 243: 205, 205 n. 30, 206 fig. 7, 208

Leiden, Universiteitsbibliotheek BPL 114: 344 n. 22

Letchworth, Sassoon Collection olim MS 368: 237, 237 n. 12, 267 olim MS 508: 267
Lisbon, Biblioteca Nacional de Portugal MS I1.72: 239 n. 14

London, British Library Cotton Roll XIV.12: 210 n. 40 MS Additional 28162: 208 n. 31 MS Additional 43120: 191-2, 192 n. 9 MS Additional 54180: 208 n. 31 MS Arundel 83 II: 197 n. 14, 203, 203 n. 27, 204 fig. 6, 220 n. 61 MS Cotton Caligula A XIV: 251, 253, 253 n. 42

MS Cotton Faustina B VII: 427

MS Harley 2253: 221, 221 n. 65

MS Harley 4751: 220 n. 63

MS Harley 5698: 268

MS Harley 5699: 268

MS Harley 5774: 267

MS Harley 5775: 267

MS Kings 1: 236-7, 236 n. 9, 241-2, 267

MS Or. 2201: 266

MS Or. 2626: 241 fig. 6, 268

MS Or. 2627: 241 fig. 6, 268

MS Or. 2628: 241 fig. 6, 268

MS Royal 2 B VII: 220 n. 63

MS Royal 10 E VII: 192 n. 9

MS Yates Thompson 13: 190 n. 5, 224 n. 73,227 n. 75

London, Lincoln's Inn MS Hale 123: 301-2 n. 81

Madison, University of Wisconsin-Madison MS 80: 410-1, 411 fig. 6 MS 170A, no. 8: 406 fig. 2

Madrid, Real Biblioteca del Palacio Real MS II, 3231-46: 268

Marseille, Bibliothèque municipale MS 1626: 266

Modena, Biblioteca Estense Universitaria MS a.0.5.9: 267 MS M.8.4: 236-7, 236 n. 9, 241-3 MS T.3.8: 236, 236 n. 9 


\section{Manuscript Studies, Vol. 4 [2019], Iss. 2, Art. 4}

Montpellier, Bibliothèque interuniversitaire, Section Médecine

H.196: 421-5

New Brunswick, Rutgers, The State

University of New Jersey, Special Collections and University Archives

MC 0886:13: 325

New York, The Jewish Theological Seminary of America

MS L.6: 269

MS L 44a: 265

New York, The Morgan Library \& Museum MS G.50: 222 n. 67

MS M.163: 299 n. 80

MS M.269: 296-7, 297 n. 70, 298 n. 74

MS M.729: 200 n. 24, 201, 201 n. 25, 202 fig. 5, 219 n. 60

MS M.791: 303-4, 304 n. 84

Oxford, Bodleian Library

MS Bodley 764: 220 n. 63

MS Can. Or. 42: 267

MS Can. Or. 137: 249 n. 33

MS Douce 366: 220 n. 63

MS Kennicott 2: 238-9, 238-9 n. 14, 267

MS Lyell 71: 210 n. 40

MS Oppenheim Add. 4º75: 239 n. 14, 266

MS Oppenheim Add. 4²76: 239 n. 14, 266

Oxford, Corpus Christi College

MS 70: 192 n. 9

Oxfordshire, Wormsley Library

Burckhardt-Wildt Apocalypse fol. 5: 203, 203 n. 28, 205

Paris, Bibliothèque de l'Arsenal

MS 65: 292 n. 58

Paris, Bibliothèque Mazarine

MS 895: 386 n. 100

MS 896: 386 n. 100
Paris, Bibliothèque nationale de France

MS Fr. 9220: 197 n. 14, 213, 213 n. 48, 215 n. 50

MS Hébreu 7: 234 fig. 2, 236, 236 n. 9, 239 fig. 5, 266

MS Hébreu 20: 239 n. 14

MS Hébreu 21: 235 fig. 3, 238-9, 238-9

n. $14,262,266$

MS Hébreu 25: 265

MS Hébreu 26: 265

MS Hébreu 31: 241, 267

MS Hébreu 1314: 237, 237 n. 12

MS Hébreu 1315: 237, 237 n. 12

MS Lat. 765: 192 n. 9, 192 n. 10, 227 n. 76

MS Lat. 4629: 344 n. 22

MS Lat. 9656: 341 n. 16

MS Lat. 10756 : 335, 343-46, 344 n. 21, 344 n. 22,345 n. 23,345 n. 24, 349-50, $357-8,357$ n. 38

Nouv. acq. fr. $13521: 342$ n. 19

Paris, Bibliothèque Sainte-Geneviève

MS 8: 301-2 n. 81

MS 2200: 213, 213 n. 48, 214 fig. 10, 215, 215 fig. 11

Paris, Compagnie des prêtres de Saint-Sulpice MS 1933: 237, 237 n. 12

Paris, École nationale supérieure des beaux-arts

Mn Mas. 4: 237, 237 n. 12

Parma, Biblioteca Palatina

MS Parm. 677: 268

MS Parm. 2025: 265

MS Parm. 2668: 233 fig. 1, 235-7, 236 n.

10, 261, 266

MS Parm. 2938: 239 n. 14

MS Parm. 3233: 240-1, 243, 266

Philadelphia, The Free Library of

Philadelphia

Lewis E 249 B: 211, 211 n. 44, 212 fig. 9

Lewis O 140: 240, 269 


\section{Dorofeeva: Visualizing Codicologically and Textually Complex Manuscripts}

\section{6 | Journal for Manuscript Studies}

Philadelphia, Science History Institute

Othmer 1: 406-9, 407 fig. 3, 408 fig. 4, 409 fig. 5

Philadelphia, University of Pennsylvania

LJS 24: 412

LJS 429: 389-90, 390 n. 1, 395-8, 396 fig 3, 397 n. 9, 398 fig. 4

Prague, Národní knihovna České republiky

XIV A 13: 251, 251 n. 41

Rochester, University of Rochester

D.460 1003-003: 361-71, 361 n. 1, 363

fig. 1, 364 n. 4, 364-5 n. 5, 365-6 n. 6, 373 n. 27, 374, 375 fig. 2, 376-388, 376

fig. 3,377 n. 30,377 n. 31,377 n. 32,377

n. 33,377 n. 34,377 n. 35,377 n. 36,377

n. 37,378 n. 38,378 n. 39,378 n. 40,378

n. 41,378 n. 42,378 n. 43,378 n. 44,378

n. 45,378 n. 46,378 n. 47,379 n. 48,379

n. 49,379 n. 50,379 n. 51,379 n. 52,379

n. 53,379 n. 54,379 n. 55,380 n. 56, 380

n. 57,380 n. 58,380 n. 59,380 n. 60,380

n. 61,380 n. 62,380 n. 63,381 n. 64,381

n. 65,381 n. 66,381 n. 67,381 n. 68,381

n. 69,381 n. 70,381 n. 71,381 n. 72,381

n. 73,382 n. 74,382 n. 75,382 n. 76,382

n. 77,382 n. 78,382 n. 79,382 n. 80,382

n. 81,383 n. 82,383 n. 83,383 n. 84,383

n. 85,383 n. 86,383 n. 87,383 n. 88,383

n. 89,383 n. 90,383 n. 91,383 n. 92,383

n. 93,384 n. 94,384 n. $95,384-5$ n. 96 ,

385 n. 97,385 n. 98,385 n. 99

Rome, Biblioteca della Comunità Israelitica

MS 3: 237, 237 n. 12, 267
Saint Petersburg, National Library of

Russia

Evr. I B 19a: 248-9, 248 n. 27, 264

Evr. II B 17: 264

Evr. II B 116: 244

Evr. II B 168: 248-9, 248 n. 27, 249 n. 31, 264

Evr. II B 269: 264

Evr. II B 1548: 245, 245 n. 25, 247, 247

fig. 8, 247-8 n. 26, 264

Evr. II C 144: 248-9, 248 n. 27, 249 n. 31, 264

Stockholm, Nationalmuseum

MS B. 1726: 187, 187-8 n. 1, 190-2, 191

n. 7,191 n. $8,227-8$

MS B. 1727: 187, 187-8 n. 1, 190-2, 191

n. 7,191 n. $8,227-8$

Vatican City, Biblioteca Apostolica

Vaticana

MS Reg. Gr. 1: 250-1, 251 n. 37, 251 n. 39, 251 n. 40, 252 fig. 9, 253, 253 n. 43

MS Ross. 601: 241-2, 242 n. 19, 265

MS Vat. lat. 1033: 362 n. 3, 377, 382 n.

76, 384-5 n. 96,385 n. 99,386 n. 100

MS Vat. lat. 1034: 362 n. 3, 377, 382 n.

76, 384-5 n. 96,385 n. 99,386 n. 100

MS Vat. lat. 1035: 362 n. 3, 377, 382 n.

76, 384-5 n. 96, 385 n. 99, 386 n. 100

MS Vat. lat. 1046: 362 n. 3

Vienna, Österreichische Nationalbibliothek Cod. Heb. 16: 249

Zurich, Braginsky Collection MS 243: 238-9, 238-9 n. 14, 243, 268 